\title{
INTEGRASI PENDIDIKAN KARAKTER DALAM PEMBELAJARAN PENDIDIKAN KEWARGANEGARAAN UNTUK MENGEMBANGKAN KARAKTER SISWA
}

\author{
Puspa Dianti, Prodi Pendidikan Kewarganegaraan, SPs, UPI
}

\begin{abstract}
ABSTRAK
Pendidikan kewarganegaraan merupakan salah satu mata pelajaran yang menjadi leading sector dalam pengembangan karakter siswa. Namun, pada kenyataannya mata pelajaran PKn belum cukup berhasil menjalankan peran tersebut secara baik karena proses yang terjadi pada pembelajaran PKn tersebut hanya berorientasi pada pencapaian kognitif saja sedangkan pencapaian afektif/sikap cenderung diabaikan. Untuk mengatasi hal tersebut perlu dilakukannya modifikasi dalam pembelajaran PKn, salah satunya dengan pengintegrasian konsep pendidikan karakter dalam kegiatan pembelajarannya sehingga lebih bisa berperan dalam pengembangan karakter siswa. Penelitian ini, dilaksanakan di SMA Unggul Negeri 4 Lahat dengan menggunakan pendekatan kualitatif dan metode studi kasus untuk menggali dan memahami kenyataan-kenyataan yang terjadi secara intensif dan mendalam berkenaan dengan integrasi pendidikan karakter pada tahap perencanaan, pelaksanaan, dan evaluasi pembelajaran PKn di sekolah tersebut. Pada penelitian ini pengumpulan data dilakukan melalui teknik observasi langsung pada kegiatan pembelajaran, teknik wawancara kepada guru dan siswa, serta melalui teknik dokumentasi. Berdasarkan hasil analisis data dapat dipahami bahwa dalam pembelajaran PKn di SMA unggul Negeri 4 Lahat sudah dilakukan pengintegrasian pendidikan karakter dalam perencanaan, pelaksanaan, dan evaluasi pembelajaran. Meskipun masih ada beberapa hal yang harus diperbaiki.selanjutnya pembelajaran yang dilakukan sangat membantu dalam pengembangan karakter siswa.
\end{abstract}

Kata kunci: pendidikan karakter, pendidikan kewarganegaraan, karakter.

\section{PENDAHULUAN}

Pembahasan mengenai karakter merupakan hal yang sangat penting dan mendasar. Kata karakter berasal dari bahasa Yunani yang berarti "to mark" atau menandai dan memfokuskan, bagaimana mengaplikasikan nilai kebaikan dalam bentuk tindakan atau tingkah laku. Jadi, baik atau buruknya karakter seseorang tercermin dalam sikap/tingkah lakunya dalam kehidupan sehari-hari. Karakter memiliki peranan yang sangat penting dalam menentukan kehidupan masa depan seseorang. Seorang Filosof Yunani, Heraclitus (dalam Lickona, 2012:12) mengatakan bahwa "Karakter adalah takdir". Karakter akan membentuk takdir seseorang. Hal tersebut juga diuraikan dalam kutipan kalimat pada buku (Lickona,2012:11), yaitu:
Hati-hati terhadap pikiran Anda, pikiran Anda menjadi kata-kata Anda. Hati-hati dengan kata-kata Anda, kata-kata Anda menjadi perbuatan Anda. Hati-hati dengan perbuatan Anda, perbuatan Anda menjadi kebiasaan Anda. Hati-hati dengan kebiasaan Anda, kebiasaan Anda menjadi karakter Anda. Hati-hati dengan karakter Anda, karakter Anda menjadi takdir Anda.

Berdasarkan pendapat Heraclitus dan kutipan kalimat di atas, jelas menunjukkan bahwa karakter terbentuk melalui suatu proses dan merupakan hal urgen yang akan sangat mempengaruhi masa depan kehidupan seseorang. Pentingnya karakter baik yang harus dimiliki oleh seseorang juga tersirat jelas pada pendapat yang dikemukakan oleh Hakim Learned Hand (dalam Budimansyah, 2010:33), yaitu: "Liberty lies in the hearts of men and 
women; when it dies there, no constitution, no law, no court can save it; no constitution, no law, no court can even do much to help it. While it lies there, it needs no constitution, no law, no court to save it."

Tidak hanya itu, karakter yang dimiliki oleh seseorang juga akan memberikan pengaruh yang luar biasa pada kelompok di mana dia berada, baik itu kelompok kecil seperti keluarga, hingga kelompok besar seperti masyarakat, bangsa, bahkan negara. Hal ini seiring dengan pendapat yang dikemukakan oleh Cicero (dalam Lickona, 2012: 12) yang menyatakan bahwa "Dalam karakter warga negara, terletak kesejahteraan bangsa." Hal ini jelas menunjukkan bahwa kumpulan karakter dari individu-individu lah yang akan mempengaruhi kesejahteraan suatu bangsa. Karakter merupakan kekuatan dan kemudian yang akan mengendalikan kehidupan suatu bangsa agar tidak terombang-ambing. Jika warga suatu negara memiliki karakter yang baik maka masa depan negara tersebut kemungkinan besar akan baik. Begitupun sebaliknya, jika warga suatu negara menunjukkan karakter yang tidak baik maka kehidupan negara tersebut kemungkinan besar juga akan tidak baik.

Hal tersebut dapat kita hubungkan dengan situasi yang ada di negara kita saat ini. Persoalan karakter terjadi hampir pada setiap elemen yang ada, mulai dari lingkungan keluarga, sekolah, masyarakat umum, bahkan para pejabat yang merupakan wakil rakyat di pemerintahan. Persoalan karakter yang nampak pada buruknya tingkah laku warga negara kita, dapat kita lihat dari pemberitaan yang ada di berbagai media massa baik cetak maupun elektronik. Hampir setiap hari, seakan tiada henti media massa memberitakan tentang kejahatan yang dilakukan oleh warga negara kita, baik itu kejahatan biasa maupun kejahatan yang luar biasa yang sebenarnya sudah sangat sulit untuk ditoleransi.

Sejauh ini, membahas mengenai solusi dari setiap permasalahan karakter yang ada, pendidikan masih menjadi bidang yang paling efektif dan efisien dalam usaha pembentukan karakter baik pada generasi muda (pelajar). Hal ini sejalan dengan pengertian pendidikan itu sendiri, seperti yang terdapat pada Undang-
Undang (UU) Sistem Pendidikan Nasional (Sisdiknas) No. 20 Tahun 2003 pasal 1 ayat 1 dalam tim redaksi sinar grafika (2003: 2) disebutkan bahwa :

Pendidikan adalah usaha sadar dan terencana untuk mewujudkan suasana belajar dan proses pembelajaran agar peserta didik secara aktif mengembangkan potensi dirinya untuk memiliki kekuatan spiritual keagamaan, pengendalian diri, kepribadian, kecerdasan, akhlak mulia, serta keterampilan yang diperlukan dirinya, masyarakat, bangsa dan negara.

Selanjutnya seiring dengan pengertian pendidikan tersebut, UU Sisdiknas No. 20 Tahun 2003 Pasal 3 dalam tim redaksi sinar grafika (2003: 5) juga menyebutkan bahwa :

Pendidikan nasional berfungsi mengembangkan kemampuan dan membentuk watak serta peradaban bangsa yang bermartabat dalam rangka mencerdaskan kehidupan bangsa, bertujuan untuk berkembangnya potensi peserta didik agar menjadi manusia yang beriman dan bertakwa kepada Tuhan Yang Maha Esa, berakhlak mulia, sehat, berilmu, cakap, kreatif, mandiri, dan menjadi warga negara yang demokratis serta bertanggung jawab.

Uraian mengenai pengertian, tujuan, dan fungsi pendidikan nasional Indonesia yang tertuang dalam UU Sisdiknas No. 20 Tahun 2003 tersebut jelas menekankan bahwa pendidikan nasional Indonesia sangat memperhatikan ketiga aspek kemampuan, yaitu kognitif, afektif, dan psikomotor. Karakter yang merupakan bagian dari aspek afektif dan psikomotor juga sangat diutamakan pencapaiannya dalam pendidikan nasional. Selain tertuang dalam UU Sisdiknas, perhatian pemerintah terhadap pembentukan karakter juga dapat dilihat dari inisiatif untuk memprioritaskan pembangunan karakter bangsa.

Pembangunan karakter bangsa dijadikan sebagai arus utama dalam pembangunan nasional. Hal tersebut menunjukkan bahwa setiap upaya pembangunan harus selalu diarahkan untuk memberi dampak positif terhadap pengembangan karakter. sesungguhnya, hal tersebut secara konstitusional telah tercermin dari misi pembangunan nasional 
yang memosisikan pendidikan karakter sebagai misi pertama dari delapan misi guna mewujudkan visi pembangunan nasional, sebagaimana tercantum pada Rencana Pembangunan Jangka Panjang Nasional tahun 2005-2025, (dalam Zubaedi, 2011: 7), yaitu:

... terwujudnya karakter bangsa yang tangguh, kompetitif, berakhlak mulia, dan bermoral berdasarkan pancasila, yang dirincikan dengan watak dan perilaku manusia dan masyarakat Indonesia yang beragam, beriman, dan bertakwa kepada Tuhan Yang Mahaa Esa, berbudi luhur, bertoleran, bergotong royong, berjiwa patriotik, berkembang dinamis, dan berorientasi iptek.

Selanjutnya, perhatian pemerintah akan permasalahan karakter juga dapat dilihat dari adanya penyusunan grand design pendidikan karakter pada tahun 2010. Pada grand design tersebut pemerintah menguraikan mengenai nilai-nilai karakter yang harus dimiliki siswa dan strategi melaksanakan pendidikan karakter tersebut. Pada grand design pendidikan karakter 2010, diuraikan bahwa pada lingkungan sekolah terdapat empat pilar yang dapat dijadikan wadah penanaman nilai-nilai karakter, yaitu kegiatan belajar mengajar di kelas yang terintegrasi pada setiap mata pelajaran, kegiatan keseharian dalam bentuk budaya satuan pendidikan (school culture), kegiatan ko-kurikuler dan/atau ekstrakurikuler, serta kegiatan keseharian di rumah, dan dalam masyarakat.

Berdasarkan keempat hal yang dapat dijadikan wadah dalam pelaksanaan pendidikan karakter di sekolah tersebut, peneliti menganggap bahwa kegiatan belajar mengajar di kelas merupakan kegiatan inti yang dilaksanakan di sekolah sehingga penerapan pendidikan karakter yang terintegrasi pada setiap mata pelajaran merupakan salah satu aspek yang harus mendapat perhatian khusus. Kegiatan belajar mengajar pada setiap mata pelajaran dapat mengintegrasikan nilai-nilai karakter yang hendak dicapai pada tiap tahap, yaitu perencanaan, pelaksanaan, dan evaluasi, termasuk juga dalam pembelajaran PKn. Apalagi dalam hal ini, peran mata pelajaran PKn merupakan leading sector dari pendidikan karakter sudah jelas harus mengintegrasikan nilai-nilai karakter dalam kegiatan belajarmengajarnya karena hal tersebut sudah jelas diuraikan dalam tujuan pembelajaran PKn seperti dijelaskan (dalam Darmadi, 2010:52), yaitu:

Membina moral yang diharapkan dapat diwujudkan dalam kehidupan sehari-hari, yaitu perilaku yang memancarkan iman dan takwa terhadap Tuhan Yang Maha Esa dalam masyarakat yang terdiri dari berbagai golongan agama, perilaku yang bersifat kemanusiaan yang adil dan beradab, perilaku yang mendukung persatuan bangsa dalam masyarakat yang beraneka ragam kepentingan, perilaku yang mendukung kerakyatan yang mengutamakan kepentingan bersama di atas kepentingan perorangan dan golongan sehingga perbedaan pemikiran, pendapatan, ataupun kepentingan di atas melalui musyawarah dan mufakat, serta perilaku yang mendukung upaya untuk mewujudkan keadilan sosial bagi seluruh rakyat Indonesia.

Berdasarkan tujuan tersebut dapat dipahami bahwa pembelajaran PKn merupakan pembelajaran yang muatannya penuh dengan nilai-nilai karakter. Namun, Permasalahan yang peneliti dapatkan di lapangan adalah praktek pendidikan dalam pembelajaran $\mathrm{PKn}$ yang berlangsung di kelas pada saat ini hanyalah sebatas pendidikan yang berorinetasi pada pencapaian tujuan kognitif atau pengetahuan saja. Sedangkan afektif, hal yang berkaitan dengan proses pembentukan karakter/sikap siswa cenderung diabaikan. Hal ini juga diperkuat oleh pendapat Suwarma (dalam Budimansyah, 2012: 450), yaitu:

Kelemahan pembelajaran PKn dalam perspektif pendidikan karakter dipertegas lebih rinci seperti kegiatan berpusat pada pendidik (teacher center), orientasi pada hasil lebih kuat, kurang menekankan pada proses, bahan disajikan dalam bentuk informasi, posisi siswa dalam kondisi pasif siap menerima pelajaran, pengetahuan lebih kuat dari pada sikap dan keterampilan, penggunaan metode terbatas pada situasi pembelajaran tidak menyenangkan dan satu arah (indoktrinasi). 
Oleh karena itu, perlunya perbaikan dalam pembelajaran PKn dalam mengembangkan karakter siswa karakter mulai dari perencanaan, pelaksanaan, dan evaluasi. Kita harus mampu melakukan perencanaan, pelaksanaan, dan evaluasi yang bisa menginternalisasikan nilainilai karakter yang ada karena penanaman nilainilai karakter tidak cukup hanya sekedar diajarkan tetapi juga harus dikembangkan. Seperti yang dikemukakan oleh Hermann dalam (Budimansyah, 2010: 68) bahwasanya "value is neither cought nor taught, it is learned". Hal tersebut dilakukan agar sebagai seorang pendidik kita mampu meghasilkan anak-anak yang tidak hanya pintar tetapi juga berkarakter.

Merujuk pada berbagai uraian masalah yang telah saya kemukakan di atas, maka saya termotivasi untuk meneliti tentang "Integrasi Pendidikan Karakter Dalam Pembelajaran Pendidikan Kewarganegaraan Untuk Mengembangkan Karakter Siswa”

\section{RUMUSAN MASALAH}

Rumusan masalah umum dalam penelitian ini adalah "Bagaimana Integrasi Pendidikan Karakter Dalam Pembelajaran PKn Untuk Mengembangkan Karakter Siswa?". Sedangkan rumusan masalah khusus dalam penelitian ini adalah:

1. Bagaimana integrasi pendidikan karakter dalam perencanaan pembelajaran $\mathrm{PKn}$ di kelas X SMA Negeri 4 Lahat?

2. Bagaimana integrasi pendidikan karakter dalam pelaksanaan pembelajaran $\mathrm{PKn}$ di kelas X SMA Negeri 4 Lahat?

3. Bagaiamana integrasi pendidikan karakter dalam evaluasi pembelajaran PKn di kelas X SMA Negeri 4 Lahat?

4. Apakah kendala-kendala yang dihadapi dalam mengintegrasikan pendidikan karakter pada pembelajaran PKn di kelas X SMA Negeri 4 Lahat?

5. Bagaimana upaya-upaya yang dilakukan untuk mengatasi kendala-kendala dalam mengintegrasikan pendidikan karakter pada pembelajaran PKn di kelas X SMA Negeri 4 Lahat?

\section{KONSEP PENDIDIKAN KARAKTER}

Pembentukan kecerdasan afektif yang berujung pada sikap/karakter individu dapat dilakukan dengan pendidikan karakter. banyak para ahli yang memberikan pengertian mengenai pendidikan karakter. Zubaedi (2012: 15) menyebutkan bahwa "Character education is the deliberate effort to cultivate virtue that is objectively good human qualities that are good for the individual person and good for the whole society."

Yang memiliki arti bahwa pendidikan karakter adalah usaha sengaja (sadar) untuk mewujudkan kebajikan, yaitu kualitas kemanusiaan yang baik secara objektif, bukan hanya baik untuk individu perseorangan tetapi juga baik untuk masyarakat secara keseluruhan.

Selanjutnya David Elkind dan Freddy Sweed dalam (Zubaedi, 2012: 15) menguraikan:

Character education is the deliberate effort to help people understand, care about, and act upon core ethical value. When we think about the kind of character we want for our children, it is clear that we want them to be able to judge what is right,care deeply about what is right, and then do what they believe to be right, even in the face of pressure from without and temptation from within.

Yang memiliki arti bahwa pendidikan karakter adalah usaha sengaja (sadar untuk membantu manusia memahami, peduli tentang, dan melaksanakan nilai-nilai etika inti. Ketika kita berpikir tentang jenis karakter yang kita inginkan bagi anak-anak, maka jelas bahwa kita mengharapkan mereka mampu menilai apakah kebenaran, peduli secara sungguh-sungguh terhadap kebenaran, dan kemudian mengerjakan apa yang diyakini sebagai kebenaran, bahkan ketika menghadapi tekanan dari luar dan upaya dari dalam. Sejalan dengan pengertian di atas, Creasy dan Zubaedi juga memberikan pemahaman mengenai pendidikann karakter.

Creasy dalam (Zubaedi, 2012: 16-17) mengemukakan bahwa:

Pendidikan karakter sebagai upaya mendorong peserta didik tumbuh dan berkembang dengan kompetensi berpikir dan berpegang teguh pada prinsip-prinsip moral dalam hidupnya serta mempunyai keberanian 
melakukan yang benar, meskipun dihadapkan pada berbagai tantangan.

Berbagai pengertian mengenai konsep pendidikan karakter yang dikemukakan oleh para ahli tersebut dapat dipahami bahwa pendidikan karakter merupakan alternatif yang dapat ditempuh dalam pembentukan karakter individu. Dalam pendidikan karakter dilakukan suatu usaha yang memang terencana/tersusun untuk membentuk individu agar memiliki kemampuan dalam menentukan dan melakukan hal-hal yang baik. Menurut beberapa pengertian pendidikan karakter di atas dapat dipahami bahwa penanaman nilai-nilai karakter bukanlah suatu pekerjaan yang mudah dan secara otomatis bisa berhasil. Pendidikan karakter harus dimulai dengan proses penanaman pengetahuan atau kecerdasan pada individu mengenai hal-hal baik yang layak dilakukan maupun tidak dan pengetahuan yang ada dapat diaplikasikan pada bentuk sikap. Dengan begitu, individu diharapkan dapat memiliki kekuatan diri dalam mempertahankan hal-hal baik tersebut meskipun ada godaan dari luar. Hal-hal baik yang dilakukan individu tersebut tidak hanya untuk dirinya sendiri tetapi juga untuk orang lain dan lingkungannya. Hal ini sesuai dengan konsep mengenai karakter bahwa karakter yang ada pada individu tidak hanya berupa kebaikan yang berguna bagi dirinya tetapi juga kebaikan untuk orang lain dan lingkungan sekitarnya.

\section{KONSEP KARAKTER}

Menurut bahasa (etimologis) istilah karakter berasal dari bahasa Latin kharakter, kharassaein, dan kharax, dalam bahasa Yunani character dari kata charassei, yang berarti membuat tajam dan membuat dalam. Dalam bahasa Inggris character dan dalam bahasa Indonesia lazim digunakan dengan istilah karakter.

Depdiknas (2010) dalam (Gunawan, 2012:2) menguraikan bahwa:

Istilah berkarakter artinya memiliki karakter, memiliki kepribadian, berprilaku, bersifat, bertabiat, dan berwatak. Individu yang berkarakter baik atau unggul adalah seseorang yang berusaha melakukan hal-hal yang baik terhadap Tuhan Yang Maha Esa, dirinya, sesama, lingkungan, bangsa dan negara, serta dunia internasional pada umumnya dengan mengoptimalkan potensi (pengetahuan) dirinya dan disertai dengan kesadaran, emosi, dan motivasinya (perasaannya).

Hal tersebut juga senada dengan yang disebutkan oleh Aqib (2012: 40) menyebutkan bahwa berdasarkan kajian nilai-nilai agama, norma-norma sosial, peraturan/hukum, etika akademik, dan prinsip-prinsip HAM, telah teridentifikasi butir-butir nilai yang dikelompokkan menjadi nilai utama, yaitunilainilai perilaku manusia dalam hubungannya dengan Tuhan Yang Maha Esa, diri sendiri, sesama manusia, dan lingkungan serta kebangsaan. Adapun secara rinci nilai-nilai tersebut adalah:

1. Hubungannya dengan Tuhan, yaitu religius. Pikiran, perkataan, dan tindakan seseorang yang diupayakan selalu berdasarkan pada nilai-nilai Ketuhanan dan/atau ajaran agamanya.

2. Hubungannya dengan diri sendiri, yaitu jujur, bertanggung jawab, bergaya hidup sehat, disiplin, kerja keras, percaya diri, berjiwa wirausaha, berpikir logis, kritis, kreatif, dan inovatif, mandiri, ingin tahu, cinta ilmu

3. Hubungannya dengan sesama, yaitu sadar akan hak dan kewajiban diri dan orang lain, patuh pada aturan-aturan sosial, menghargai karya dan prestasi orang lain, santun, demokratis.

4. Hubungan dengan lingkungan, yaitu peduli akan sosial dan lingkungan ditunjukkan dengan sikap dan tindakan selalu berupaya mencegah kerusakan pada lingkungan alam sekitarnya, dan mengembangkan upaya-upaya untuk memperbaiki kerusakan alam yang sudah terjadi dan selalu ingin memberi bantuan bagi orang lain dan masyarakat yang membutuhkan.

5. Nilai kebangsaan, yaitu nasionalis dan menghargai keberagaman.

\section{KONSEP PEMBELAJARAN PENDIDIKAN KEWARGANEGARAAN}

Menurut Budimansyah (dalam

Komalasari, 2010: 264-265) bahwa dalam paradigma baru, pendidikan kewarganegaraan 
(civic education) merupakan salah satu bidang kajian yang mengemban misi nasional untuk mencerdaskan kehidupan bangsa Indonesia melalui koridor "value based education" dengan kerangka sistematik sebagai berikut:

1. Secara kurikuler bertujuan untuk mengembangkan potensi individu agar menjadi warga negara Indonesia yang berakhlak mulia, cerdas, partisipatif, dan bertanggung jawab.

2. Secara teoritik memuat dimensi-dimensi kognitif, afektif, dan psikomotorik yang bersifat konfluen atau saling berpenetrasi dan terintegrasi dalam konteks substansi ide, nilai, konsep, dan moral pancasila, kewarganegaraan yang demokratis, dan bela negara.

3. Secara programatik menekankan pada isi yang mengusung nilai-nilai dan pengalaman belajar dala bentuk berbagai perilaku yang perlu diwujudkan dalam kehidupan seharihari dan merupakan tuntunan hidup bagi warga negara dalam kehidupan bermasyarakat, berbangsa, bernegara sebagai penjabaran lebih lanjut dari ide, nilai, konsep, dan moral pancasila, kewarganegaraan yang demokratis dan bela negara.

Ketiga kerangka sistematik pendidikan kewarganegaraan tersebut menjelaskan bahwa pendidikan kewarganegaraan merupakan mata pelajaran yang mengemban misi pendidikan nilai. Hal tersebut juga jelas tergambar pada tujuan dan fungsi dari Pendidikan Kewarganegaraa.

\section{Secara}

Kewarganegaraan mengembangkan potensi individu warga negara Indonesia yang memiliki wawasan, disposisi, serta keterampilan intelektual dan sosial kewarganegaraan yang memadai, yang memungkinkan untuk berpartisipasi secara cerdas dan bertanggung jawab dalam berbagai dimensi kehidupan bermasyarakat, berbangsa, dan bernegara. Selain itu, PKn juga memiliki fungsi sebagai wahana untuk membentuk warga negara yang cerdas, terampil, dan berkarakter yang setia kepada Bangsa dan Negara Indonesia dengan merefleksikan dirinya dalam kebiasaan berpikir dan bertindak sesuai dengan amanat
Pancasila dan UUD NRIT 1945 (Depdiknas, 2001: 5)

Selanjutnya, menurut Soemantri (2001: 166) fungsi Pendidikan Kewarganegaraan, yaitu: "Usaha sadar yang dilakukan secara ilmiah dan psikologis untuk memberikan kemudahan belajar kepada peserta didik agar terjadi internalisasi moral Pancasila dan pengetahuan Kewarganegaraan untuk melandasi tujuan pendidikan nasional, yang diwujudkan dalam integritas pribadi dan perilaku seharihari."

\section{METODE PENELITIAN}

Penelitian ini menggunakan pendekatan kualitatif dengan metode studi kasus untuk menggali secara mendalam mengenai pengintegrasian pendidikan karakter dalam pembelajaran PKn mulai dari tahap perencanaan, pelaksanaan, dan evaluasi pembelajaran. Peneliti melakukan analisis terhadap berbagai data yang didapatkan di lapangan. Adapun pegumpulan data dilakukan melalui berbagai teknik, yaitu observasi kegiatan pembelajaran di kelas, wawancara dengan para guru dan siswa, serta melihat dokumentasi berupa silabus dan RPP yang digunakan oleh guru.

\section{HASIL DAN PEMBAHASAN}

Berdasarkan grand design pendidikan karakter tahun 2010, diuraikan bahwa pada lingkungan sekolah terdapat empat pilar yang dapat dijadikan sebagai wadah penanaman nilainilai karakter. Di antara keempat wadah tersebut salah satunya adalah melalui kegiatan belajarmengajar di kelas yang diintegrasikan pada setiap mata pelajaran termasuk dalam hal ini yaitu mata pelajaran PKn. Setiap mata pelajaran yang diberikan pada siswa di kelas diharapkan dapat memberikan dampak pembentukan karakter kepada siswa. Dalam hal ini ada yang disebut dengan dampak instruksional dan dampak pengiring (nurturant effect).

Mata pelajaran PKn sesungguhnya merupakan salah satu mata pelajaran yang kaya akan nilai-nilai karakter. PKn merupakan salah satu leading sector dari pembelajaran berkarakter. Oleh karena itu tujuan karakter yang ditetapkan dalam pembelajaran PKn 
sesungguhnya merupakan dampak instruksional yang ingin dicapai bukan hanya sebatas dampak pengiring saja. Namun, pada kenyataan saat ini PKn seakan menjadi mata pelajaran yang tidak dianggap begitu penting karena pelajaran PKn hanya sebatas pada kegiatan menghapal materi dan kurang mampu menjalankan fungsinya sebagai leading sector dari pendidikan karakter. Pada tahap perencanaan pembelajaran, maka yang harus dilakukan adalah mempersiapkan silabus dan Rencana Pelaksanaan Pembelajaran (RPP). Oleh karena itu, pada penelitian ini saya melakukan analisis terhadap silabus dan RPP yang dipersiapkan oleh guru dalam mendukung pembelajaran PKn berkarakter di kelas. Perencanaan pada pembelajaran yang dituangkan pada RPP memiliki fungsi yang besar dalam menyukseskan pendidikan karakter dalam pembelajaran. Hal ini didukung oleh pendapat yang dikemukakan oleh Mulyasa (2013: 82) yang menguraikan bahwa sedikitnya terdapat dua fungsi RPP dalam menyukseskan pendidikan karakter di sekolah, yaitu:

1. Fungsi perencanaan.

Dalam implementasi pendidikan karakter di sekolah, RPP berfungsi untuk mendorong setiap guru agar lebih siap dalam melakukan kegiatan pembelajaran, membentuk kompetensi, dan karakter peserta didik dengan perencanaan yang matang.

2. Fungsi pelaksanaan.

Untuk menyukseskan implementasi pendidikan karakter di sekolah RPP harus disusun secara sistematik dan sistematis, utuh dan menyeluruh, dengan beberapa kemungkinan penyesuaian dalam situasi pembelajaran yang aktual. Dalam hal ini, materi standar yang dikembangkan dan dijadikan bahan kajian oleh peserta didik harus disesuaikan dengan kondisi dan kebutuhan lingkungan, sekolah, dan daerah.

Pendapat Mulyasa tersebut juga diperkuat oleh pendapat Joseph dan Leonard dalam (Mulyasa, 2013:85) yang mengemukakan bahwa "Teaching without adequate written planning is sloppy and almost always ineffective, because the teacher has not thought out exactly what to do and how to do it.". Kedua pendapat tersebut jelas menegaskan bahwa seorang guru yang akan memberikan pembelajaran di kelas harus membuat perencanaan mengenai hal-hal apa saja yang akan dilaksanakan dalam pembelajaran di kelas. Begitu pentingnya perencanaan pembelajaran ini, maka pembuatan rencana tersebut harus dilakukan secara baik dan benar.

Pada penelitian integrasi pendidikan karakter dalam pembelajaran PKn di SMA Negeri 4 Lahat, peneliti juga melakukan pengumpulan data dokumentasi berupa silabus dan RPP yang dipersiapkan oleh guru PKn. Berdasarkan silabus dan RPP yang peneliti dapatkan dari guru, peneliti melihat bahwa guru sudah melakukan modifikasi pada beberapa komponen dalam pembuatan silabus dan RPP. Pada pembuatan silabus dan RPP guru telah melakukan modifikasi dengan menambahkan langsung jenis karakter yang ingin dicapai setelah kegiatan pembelajaran. Hal ini sesuai dengan pedoman dari pembuatan RPP berkarakter yang dikemukakan dalam Gunawan (2012: 226) bahwa salah satu hal yang harus dimodifikasi dalam silabus untuk memfasilitasi terjadinya pembelajaran yang membantu peserta didik mengembangkan karakter adalah "Penambahan dan/atau modifikasi indikator pencapaian sehingga ada indikator yang terkait dengan pencapaian peserta didik dalam hal pembentukan karakter." Selain itu, berkaitan dengan modifikasi dalam RPP, peneliti juga melihat bahwa di dalam RPP yang dibuat oleh guru, telah dilakukan modifikasi dalam indikator pembelajaran. Pada RPP guru telah menambahkan secara khusus jenis karakter yang ingin dicapai dalam kegiatan pembelajaran. Hal ini menunjukkan bahwa guru telah melakukan modifikasi RPP berkarakter yang sesuai dengan pedoman dari Depdiknas yang dikutip dalam Mulyasa (2013: 102) hal yang harus ditempuh oleh guru dalam mengembangkan RPP berkarakter, yaitu:

Mengidentifikasi atau mengelompokkan karakter yang ingin dicapai setelah proses pembelajaran. Identifikasi karakter perlu dilakukan sebaik-baiknya karena kesalahan dalam mengidentifikasi karakter dapat mengaburkan makna dan hakikat pembelajaran. Terdapat beberapa hal yang perlu diperhatikan dalam mengidentifikasi karakter, yaitu hendaknya mengandung unsur 
proses dan produk, bersifat spesifik dan dinyatakan dalam bentuk perilaku nyata, mengandung pengalaman belajar yang diperlukan untuk mencapai karakter tersebut, pembentukan karakter seringkali membutuhkan waktu relatif lama, harus realistis dan dapat dimaknai sebagai kegiatan atau pengalaman belajar tertentu.

Selanjutnya, hal lain yang dapat dilihat dari silabus berkarakter yang dipersiapkan oleh guru, peneliti melihat bahwa guru belum begitu melakukan modifikasi dalam komponen teknik penilaian karena pada silabus tersebut tidak ada penambahan/modifikasi pada komponen teknik penilaian. Untuk komponen ini guru sudah mencoba untuk memilih bentuk penilaian tes tertulis dan pengamatan terhadap sikap siswa. Namun, bentuk penilaian tertulis yang diberikan oleh guru hanya sebatas latihan-latihan soal yang menurut peneliti hanya mampu melihat kemampuan kognitif siswa saja, sedangkan untuk pengamatan sikapnya guru hanya melakukan sendiri dan kurang melibatkan peran aktif siswa. Misalnya dengan mengajak siswa melakukan penilaian terhadap diri sendiri atau bisa juga menggunakan bentuk penilaian antar teman. Oleh karena itu peneliti merasa bahwa guru masih kurang maksimal dalam melakukan modifikasi silabus pada komponen kegiatan pembelajaran dan teknik penilaiannya. Seharusnya guru lebih melakukan perubahan dan kreatifitas pada tahap tersebut karena kedua komponen tersebut merupakan bagian penting yang harus dimodifikasi agar mendukung pembelajaran berkarakter. Hal ini sesuai dengan pedoman pengembanagan silabus berkarakter Depdiknas yang dikutip dalam Gunawan (2012: 226) bahwa untuk memfasilitasi terjadinya pembelajaran yang membantu peserta didik mengembangkan karakter perlu dilakukan:

a. Penambahan dan/atau modifikasi kegiatan pembelajaran sehingga memuat kegiatan pembelajaran yang mampu mengembangkan nilai-nilai karakter yang diinginkan.

b. Penambahan dan/atau modifikasi teknik penilaian sehingga ada teknik penilaian yang dapat mengembangkan dan/atau mengukur perkembangan karakter.
Selanjutnya analisis dokumentasi pada RPP, peneliti juga mengamati komponenkomponen lain, seperti pemilihan metode, kegiatan pembelajaran, media, sumber belajar, dan evaluasi pembelajaran. Pada RPP dengan Standar Kompetensi menganalisis sistem politik di Indonesia yang terdiri atas empat kompetensi dasar dan diajarkan selama enam kali pertemuan, peneliti melihat bahwa pada setiap pertemuan guru sudah merencanakan untuk menggunakan cukup beragam sumber, media, dan metode pembelajaran. Pada setiap pertemuan guru menggunakan cukup beragam sumber belajar seperti buku-buku pelajaran $\mathrm{PKn}$, internet, informasi/berita dari berbagai media baik cetak ataupun elektronik, dan juga menggunakan sumber belajar langsung, yaitu siswa diarahkan untuk belajar langsung dari lingkungan. Selanjutnya, guru juga menggunakan beragam media pembelajaran untuk mendukung berhasilnya pengembangan karakter siswa. media yang rencananya akan digunakan oleh guru adalah power point/slide sebagai sarana guru untuk menjelaskanmateri, selanjutnya guru akan menampilkan berbagai video, film-film pendek, gambar, selanjutnya juga media internet untuk membantu siswa memperdalam informasi yang berkaitan dengan materi yang sedang dipelajari.

Kemudian, berkaitan dengan metode pembelajaran, sama hal nya dengan media dan sember belajar. Guru juga telah merencanakan beragam metode pembelajaran dalam mendukung keberhasilan pengembangan karakter siswa. adapun metodenya adalah ceramah, kegiatan tanya jawab, diskusi kelompok, problem solving atau pemecahan masalah, menonton video/film, observasi langsung ke lapangan, dan inkuiri. Berbagai metode yang direncanakan oleh guru tersebut diharapkan dapat membantu mengembangkan karakter siswa. Secara tidak langsung karakterkarakter yang ingin dikembangkan dapat diintegrasikan pada metode-metode pembelajaran yang digunakan. Penggunaan metode yang beragam dan mampu meningkatkan keaktifan dan kreativitas siswa disarankan untuk mendukung keberhasilan pengembangan karakter siswa. Hal ini sesuai dengan pedoman penyusunan RPP berkarakter 
dari Depdiknas yang dikutip oleh Mulyasa (2013:102) bahwa:

Penentuan metode pembelajaran erat kaitannya dengan pemilihan strategi pembelajaran yang paling efektif dan efisien dalam memberikan pengalaman belajar yang diperlukan untuk membentuk karakter peserta didik. Dalam setiap pembelajaran dan pembentukan karakter peserta didik, guru dapat menggunakan berbagai variasi metode, dan berbagai variasi media untuk mencapai tujuan pembelajaran. Dalam hal ini guru diharapkan dapat memilih dan menggunakan berbagai metode dan media pembelajaran yang dapat menumbuhkann aktivitas dan kreativitas peserta didik.

Namun, walaupun pada komponen media, metode, sumber belajar guru telah merencanakan dengan baik, tetapi pada komponen evaluasi atau penilaiannya peneliti melihat bahwa guru belum merencanakan teknik penilaian yang beragam. Pada RPP guru hanya merencanakan bentuk penilaian tes tertulis dan pengamatan sikap siswa saja. Pada penilaian dengan tes tertulis peneliti mengamati bahwa soal-soal tertulis yang dipersiapkan oleh guru hanya sebatas pada pengukuran kognitif saja. Sedangkan pengamatan sikap terhadap siswa dilakukan hanya oleh guru saja dan tidak melibatkan siswa, seperti penilaian diri yang dilakukan oleh siswa dan penilaian antar teman. Penilaian yang dapat membantu mengukur perkembangan karakter siswa tersebut di antaranya adalah melalui observasi/ pengamatan sikap siswa selama proses atau setelah pembelajaran baik yang dilakukan oleh guru ataupun juga melibatkan siswa melalui penilaian diri atau penilaian antarteman. Selanjutnya bentuk penilaian juga bisa berupa anecdit record, skala bertingkat, wawancara terhadap siswa, dan portofolio.

Selanjutnya, Berdasarkan data dari observasi dan hasil wawancara, maka peneliti mengamati bahwa pada langkah-langkah pembelajaran PKn yang dilakukan, guru telah berupaya untuk mengintegrasikan nilai-nilai karakter yang hendak dicapai dari kegiatan pembelajaran. Mulai dari tahap pendahuluan, inti, dn penutup. Pada tahap pendahuluan guru melakukan hal-hal yang mampu menyisipkan nilai-nilai karakter pada setiap tahapnya, seperti guru mempersiapkan keadaan kelas dan siswa sebelum memulai pelajaran, kemudian mengabsensi dan menanyakan kabar siswa, melakukan apersepsi dengan menanyakan kepada siswa materi sebelumnya dan mencoba menghubungkan dengan materi sekarang, guru juga menyampaikan kompetensi dan cakupan materi yang akan dipelajari. Kegiatan pendahuluan yang dilakukan oleh guru tersebut sudah sesuai dengan standar proses seperti yang dikemukakan oleh Gunawan (2012: 230), yaitu:

1. Guru harus menyiapkan peserta didik secara psikis maupun fisik untuk mengikuti proses pembelajaran. Persiapan psikis yang dilakukan oleh guru dapat dimulai dengan berdoa kemudian menanyakan kabar siswa, kesiapan siswa untuk memulai pelajaran, dan lain-lain. Sedangkan persiapan fisik dapat dilakukan dengan mengkondisikan situasi kelas.

2. Mengajukan pertanyaan-pertanyaan yang mengaitkan pengetahuan sebelumnya dengan materi yang akan dipelajari atau sering disebut dengan apersepsi.

3. Menjelaskan kepada siswamengenai tujuan pembelajaran atau kompetensi dasar yang akan dicapai dalam kegiatan pembelajaran.

4. Menyampaikan kepada siswa mengenai cakupan materi dan penjelasan uraian kegiatan sesuai silabus.

Selanjutnya, tahapan kegiatan inti. Pada tahapan kegiatan inti guru mencoba menyampaikan materi pembelajaran dengan berusaha melibatkan siswa secara aktif. Inti dari pembelajaran berkarakter adalah siswa dilibatkan untuk lebih banyak terlibat, jadi pembelajaran tidak hanya berpusat kepada guru melainkan kepada siswa. Pada langkah-langkah pembelajaran di kegiatan inti guru telah mencoba untuk lebih banyak melibatkan siswa, misalnya dalam penyampaian materi guru hanya menyampaikan secara umum saja dan siswa diarahkan untuk menggali sendiri informasi secara mendalam dari berbagai sumber, selanjutnya guru sering menampilkan berbagai video atau film yang berhubungan dengan materi. Pada kegiatan ini, guru mengarahkan siswa untuk mengamati tayangan video atau film dan diminta memberikan komentarnya. Hal 
lain juga yang dilakukan oleh guru pada kegiatan inti adalah siswa sering dilatih untuk berdiskusi memecahkan permasalahan secara bersama-sama. Hal tersebut sesuai dengan teori mengenai pembelajaran aktif dalam PKn yang dikemukakan oleh Cholisin (2011: 6-7) bahwa pembelajaran aktif dalam PKn antara lain dilaksanakan melalui kegiatan sebagai berikut:

1. Mencari informasi dari berbagai sumber seperti buku teks, surat kabar, majalah, tokohmasyarakat .

2. Membaca dan menelaah ( studi pustaka)

3. Mendiskusikan..

4. Mempresentasikan.

5. Memberi tanggapan.

6. Memecahkan masalah atau kasus.

7. Mengamati/mengobservasi.

8. Mensimulasikan.

9. Mendemonstrasikan.

10. Memberikan contoh.

Selanjutnya, tahapan terakhir dalam pembelajaran, yaitu kegiatan penutup. Pada kegiatan penutup seorang guru juga harus mampu mengintegrasikan nilai-nilai karakter. Berdasarkan data observasi dan wawancara, guru telah melakukan kegiatan penutup dengan baik dalam membantu mengembangkan karakter siswa karena apa yang dilakukan oleh guru pada kegiatan penutup telah sesui dengan teori yang dikemukakan oleh Gunawan (2011: 233-234) yang menyatakan bahwa pada kegiatan penutup pembelajaran berkarakter terdapat beberapa langkah yang harus dilakukan, yaitu:

1. Bersama-sama dengan peserta didik dan/atau sendiri membuat rangkuman/simpulan pelajaran (contoh nilai yang ditanamkan mandiri, kritis, kerjasama, kritis, logis)

2. Melakukan penilaian dan/atau refleksi terhadap kegiatan yang sudah dilaksanakan secara konsisten dan terprogram (contoh nilai yang ditanmkan jujur, mengetahui kelebihan dan kekurangan)

3. Memberikan umpan balik terhadap proses dan hasil pembelajaran (contoh nilai yang ditanamkan saling menghargai, percaya diri, santu,kritis, logis)

4. Merencanakan kegiatan tindak lanjut dalam bentuk pembelajaran remedi, program pengayaan, layanan konseling dan/atau memberikan tugas, baik tugas individual maupun kelompok sesuai dengan hasil belajar peserta didik

5. Menyampaikan rencana pembelajaran pada pertemuan berikutnya.

Langkah-langkah yang disebutkan di atas, telah dilakukan oleh guru pada kegiatan penutup, dimana guru telah mengajak siswa untuk menyimpulkan materi pembelajaran bersamasama, kemudian memberikan kesempatan kepada siswa untuk mengomentari atau memberikan penilaian terhadap kegiatan pembelajaran yang telah dilalui, serta bisa memberikan saran untuk kegiatan pembelajaran selanjutnya, dan terakhir guru selalu menyampaikan materi selanjutnya dan menutup dengan salam.

Selanjutnya, Berdasarkan data yang peneliti dapatkan melalui observasi langsung kegiatan pembelajaran $\mathrm{PKn}$, dan wawancara dari guru serta beberapa orang siswa, peneliti melihat bahwa bentuk evaluasi atau penilaian yang dilakukan dalam pembelajaran PKn belum begitu baik karena ketika pembelajaran di kelas, peneliti melihat bahwa guru tidak menggunakan teknik penilaian yang beragam. Guru hanya melakukan penilaian berupa penilaian terhadap tugas siswa dalam bentuk tertulis, selanjutnya guru juga melakukan penilaian dengan memberikan pertanyaan langsung kepada siswa di akhir pelajaran yang menurut peneliti hanya sebatas pada pengukuran kognitif saja, selanjutnya guru sudah melakukan penilaian terhadap sikap siswa selama proses pembelajaran . Namun, belum dilakukan secara terus-menerus.

Data yang sama juga peneliti dapatkan dari hasil wawancara dengan beberapa orang siswa, yang menyatakan bahwa guru hanya melakukan penilaian dalam bentuk tertulis, pemberian pertanyaan langsung secara lisan, dan penilaian ketika pelaksanaan diskusi. Hal tersebut menunjukkan bhawa guru belum maksimal dalam melakukan evaluasi pembelajaran berkarakter. hal ini dapat dilihat dari teori berbagai teori penilaian pembelajaran berkarakter, yaitu, melalui observasi, wawancara, anecdot record, skala bertingkat, penilaian diri, penilaian antar teman, dan juga portofolio. 
Pada penelitian ini, peneliti juga mencoba mengamati hambatan-hambatan yang dihadapi oleh guru dalam mengintegrasikan konsep pendidikan karakter dalam tahap perencanaan, pelaksanaan, dan evaluasi pembelajaran. Pada tahap perencanaan terkadang guru diminta untuk melengkapi hal-hal yang bersifat administratif sehingga penyusunannya tidak terlalu baik. Selanjutnya pada tahap pelaksanaan kendalanya adalah waktu. Terkadang untuk melakukan bentuk pembelajaran yang ideal dalam mendukung pengembangan karakter siswa dibutuhkan waktu yang lebih banyak. Selanjutnya permaslahan juga berasal dari luar. Banyaknya contoh-contoh yang tidak baik di luar membuat guru kesulitan untuk menjelaskan hal-hal baik yang ada kepada siswa.

Dalam mengantisipasi permasalahan pada tahap perencanaan, biasanya guru mencoba memaksimalkan pada tahap pelaksanaan saja meskipun silabus dan RPP yang disiapkan tidak sempurna. Selanjutnya mengatasi permasalahan kurang nya waktu, guru sebisa mungkin mengedit kegiatan yang ada disesuaikan dengan waktu yang tersedia. Sedangkan untuk permasalahan banyaknya contoh-contoh yang kurang baik di luar membuat guru harus lebih ekstra memberikan penguatan kepada siswa mengenai nilai-nilai yang baik.

\section{PENUTUP}

Integrasi pendidikan karakter dalam pembelajaran PKn merupakan solusi yang dapat membangkitkan kembali peran PKn sebagai mata pelajaran yang merupakan leading sector dalam pengembangan karakter siswa. PKn merupakan mata pelajaran PKn yang dalam muatan materinya sudah kaya akan nilai-nilai karakter akan semakin membantu dengan diintegrasikannya konsep pendidikan karakter. Pengembangan karakter siswa tidak hanya dikembangkan melalui muatan materi PKn saja, tetapi karakter siswa dapat dikembangkan secara tidak langsung melalui tahapan dalam kegiatan pembelajaran, selanjutnya jga bisa didukung dengan penggunaan metode, media, dan sumber pembelajaran.
Integrasi pendidikan karakter dalam pembelajaran sudah harus dipersiapkan mulai dari tahap perencanaan, pelaksanaan, dan evaluasi pembelajaran. Pada tahap perencanaan sudah harus dipersiapkan materi, metode, media, sumber belajar, tahapan kegiatan pembelajaran, dan evaluasi yang akan digunakan untuk mendukung pelaksanaan pendidikan karakter tersebut. Komponenkomponen pembelajaran tersebut secara tidak langsung dapat membantu mengembangkan jenis karakter yang telah ditetapkan.

\section{DAFTAR PUSTAKA}

Aqib, Z. 2012. Pendidikan Karakter Di Sekolah (Membangun Karakter Dan

Kepribadian Anak). Bandung: Yrama Widya.

Budimansyah, D. 2010. Penguatan Pendidikan

Kewarganegaraan Untuk Membangun

Karakter Bangsa. Widya Aksara Press: Bandung.

\section{Dimensi-Dimensi}

Praktik Pendidikan Karakter. Bandung:

Widya Aksara Press.

Cholisin. 2011. Pengembangan Karakter Dalam

Materi Pembelajaran Pkn. Yogyakarta:

Universitas Negeri Yogyakarta.

Darmadi, H. 2010. Pengantar Pendidikan

Kewarganegaraan. Bandung: Alfabeta

Gunawan, H. 2012. Pendidikan Karakter

(Konsep dan Implementasi).

Bandung:Alfabeta.

Komalasari, K. 2010. Pembelajaran kontekstual

(konsep dan aplikasi). Bandung: PT

Refika Aditama.

Lickona, T. 2012. Character Matters. Jakarta:

PT Bumi Aksara.

Mulyasa. 2013. Manajemen Pendidikan

Karakter. Jakarta: Bumi Aksara.

Zubaedi. 2012. Desain Pendidikan Karakter

(Konsepsi Dan Aplikasinya Dalam

Lembaga Pendidikan). Kencana Prenada

Media Group: Jakarta.

Undang-Undang Sistem Pendidikan Nasional

(SISDIKNAS) No 20 Tahun 2003. 